\title{
Strategies Adopted By The Adventist Centre In Enhancing Livelihood Sustainability Among Beneficiaries In Kibagare Slum
}

\author{
Isabella Ongere \\ Fedha Mukhwana \\ John Omboto
}

\begin{abstract}
A livelihood strategy is an organized set of lifestyle choices, goals and values, and activities which Non Governmental Organizations are allowed a flexibility to adopt in order to built and improve livelihoods. Inspite of well documented NGO interventions towards the improvement of livelihoods of urban slum populations, effects of these projects are hardly felt after their exit. It is against this background that this paper addresses the livelihood strategies adopted by Adventist Centre to enhance livelihood sustainability among beneficiaries. The study involved 105 beneficiaries and $10 \mathrm{key}$ informants selected by probability and non probability sampling method. Primary data was collected from the beneficiaries through interviews and questionnaires while secondary data was collected from the AC records such as minutes, policy documents, donor agency correspondencies, operating manual/procedures, grant approval procedures and memorandums of approval. This paper addresses the findings of this research conducted by the author at Kibagare slum, in Nairobi county, Kenya. It discusses the strategies adopted by AC, factors that affect the strategies and the strategies that were most effective and finally recommends on effective ways strategies should be adopted. Recommendations on how to ensure strategies covered all the elements that contribute to sustainable livelihoods that AC needed to develop were recommended.
\end{abstract}

Key words: Sustainability, Livelihood, Strategy, Kenya

INTRODUCTION

Approaches by NGOs who adopt strategies for livelihood sustainability should be place focused, actor oriented and context specific (Bell and Morse, 2003). While research focus has been mostly on vulnerability on poor communities, other research studies have worked, focused from a vulnerability and social security perspectives; several on disturbances and local vulnerabilities De Haan and zoomers (2005). Other investigations are also focused on adaptation that includes short term and long term sustainability. Different political governments have in place frameworks through which programs are provided. However, despite the daunting strides governments make in improving the livelihoods of beneficiaries, it is not possible to meet their optimum expectations. It is on the basis of this that NGOs are allowed a flexibility and autonomy to operate. However, some NGOs working in Kenyan slums are today more or less like business (kiosks) empires, which are quick to produce neatly authored monitoring and evaluations reports for their donors but whose real impact is rarely felt by the target populations (NGO Coordination Board.

\section{LITERATURE REVIEW: STRATEGIES FOR ENHANCING LIVELIHOOD SUSTAINABILITY}

According to (De Haan and zoomers, 2005), a livelihood concept is about individuals, households or groups making a living, attempting to meet their various consumption and 
economic necessities, coping with uncertainties and responding to new opportunities. However, for decades survey after survey reveal that most strategy implementations plans do not necessarily enhance livelihoods as intended even after seemingly viable plans have been developed. This paper uses strategies adopted by AC to sustain livelihoods of Kibagare beneficiaries, factors that affect sustainability and to established the most effective strategy that strategy.

The concept of livelihood sustainability has gained wide acceptance among donor agencies due to the day to day uncetainity of survival. It is adopted among the rural and urban populations in major parts of the world. This trend has existed since the 1960 with particular attention paid to the world of lived experience, at the household levels, social networks and the community (Dehaan and Zoomers, 2005). Matanga (2010) states that NGOs constitute important stakeholders in contributing towards sustainable livelihoods to help the poor and the weak to organize their communities in order to achieve sustainable livelihoods.

According to Adam (2013) livelihoods are the means of a living; how to think about them, the way people live their own life and their needs to live it in a proper way. In this definition of livelihood, Ellis, (2000) also identified three important variables comprising assets, activities and access. These assets are mediated by institutional and social relation processes for the ultimate outcome of livelihood strategies. A livelihood program should help the poor to gain better access to opportunities and may turn out to be sustainable and more cost effective (Ellis, 2000).

Various studies indicate that there exist many approaches by which nongovernmental organizations can use to ensure program sustainability. Without well planned strategy implementation program, no strategy would be implemented regardless of its superiority (Journal of Business Ethics). Other studies have also revealed that different NGOs adopt and implement different strategies that are in line with their objectives. In different perspectives strategies adopted by NGOs are engaged in activities as diverse as grassroot mobilization, community empowerment, micro finance, water and sanitation, education and training, health, agriculture and food security, and energy (Lewis , 2006). The point of convergence in this study is that sustainable livelihoods can be viewed from a variety of different circumstances all the way from a project through to a programme and finally to a policy level. Matanga (2010) states that most organizations adopt strategies to help the poor and weak to organize communities in order to achieve self-sustainability. This is one of the approaches where nongovernmental organizations initiate ventures that are revenue generating to supplement the income raised from donors, grants and well-wishers de Han and Zoomers (2005). Other approaches include building a culture that promotes volunteerism, cooperation and giving among the local society members. This has been found to be a key approach in operationalizing strategy as an important aspect of attaining self- sufficiency (Ameer \& Othman, 2012).

According to Claessens (2011), sustainability is important for continued operations of the nongovernmental organizations in execution of its programs. It entails the ability to come up with diverse resource base to enable continued provision of goods and services to the targeted beneficiaries beyond the financial support period by main donors. This is supported by Aipinge (2015) who state that for an organization to survive, it should have the ability to acquire and maintain resources. For NGOs to achieve their goals, it is necessary to promote a healthy financial position that is necessary for their growth and survival.

Sustainability and Sustainable Development in contemporary development work can be described as the most used, over used and abused concept. Every year, many millions of dollars 
are invested by national governments and international donor agencies alike in project implementation for the good of beneficiaries. Yet many still fail to ensure the sustainability of targeted projects. Lewis (2006) reported there are about 1 million NGO's working all over the world. Existence of these NGOs is not only pronounced in developing countries but those that cuts across developed and developing nations where they adopt varying degrees of strategies, objectives and missions to fulfill their developmental agenda.

In Africa Structural Adjustment Programs (SAP) were implemented by governments as advocates for the vulnerable in society. They were considered better to mitigate the social impacts of society (USAID, 2015). The (SAP) programs were not by any means implemented to undermine innovative projects that communities have successfully implemented through the support of some of these NGOs. The growth in the number of NGOs was a direct response to the negative impacts of certain government policies or issues that have not received wide governmental attention. There is almost nowhere in Africa that does not have some kind of contact with NGOs as they have found favor in bodies like United Nations, European Union, International Monetary Fund and the World Bank and other bilateral and multilateral organizations who believe they are an important part to put African governments in check on issues of mal-administration and human rights (UN, 2011). At the time of study, over eleven thousand NGOS were registered but only about eight thousand were active an in the country working on issues from human rights to maternal health and conservation (NGO Board 2016). In Nairobi slums for instance, there exists 'professors' in all fields possible - from urban planning \& architecture to land management, social work, engineering, micro-finance, community health, political science and many others. Sadly, these experts, who have accumulated years of knowledge, have been overshadowed by conventional professionals and their expertise often goes unrecognized. Even in these very important and complex environments, there is considerable NGO activity especially in urban slums where expats are engaged in varying interventions aimed to better the lot of beneficiaries who are generally considered in the country as deprived (NGO Coordination Board). According to Ahmed (2012) strategies that are well formulated end up not well implemented because of challenges in strategy implementation. Well implemented strategies lead to realization of better organizational performance. Amagoh \& Kabdiyeva (2012) posits that for performance to be realized, measures have to be put in place to ensure effective implementation of the strategy. According to Journal of Business Ethics, most organizations do not report good performance outcomes because the organizations and their managers forget the vital role of strategy implementation.

\section{STUDY AREA AND METHODOLOGY}

The study was conducted at Kibagare slum in Westlands division, Nairobi County which is about $15 \mathrm{~km}$ west of the city centre of Nairobi and lies between Loresho Estate and Kitisuru estates. At the time of study, the total population was 15000 with 1477 households (Government of Kenya, 2011). The predominant ethnic groups living in Kibagare comprises of communities drawn from the Luhya, Abagusii, Kamba, Kikuyu and Luo. The main source of income for the people is small businesses and menial jobs in the neighboring splendid Loresho estate in the Lower Kabete Area. AC was the NGO under study. It was initiated by the Nairobi Central Seventh Day Adventist Church in the year 2005. The broad areas that AC has intervened in since inception include:- HIV/AIDS prevention and management programs Behaviour change; abstinence, Be faithful and HIV/AIDS counseling and testing programs; referrals; Post Test Clubs, economic empowerment; OVC interventions; health and nutrition for the disadvantaged and vulnerable groups; poverty alleviation; youth capacity building that included life-skills training and micro-finance. 
The study participants were 105 beneficiaries selected from four communities of Kibagare. They were selected using a formula provided by Miller and Brewer (2003). Purposive sampling was to select 10 key informants that included one Program Coordinator, and four supervisors attached to the four villages of Kibagare, one area Chief and four village elders. The study employed a probability and non probability sampling technique. The unit of analysis were AC staff responsible for program implementation and the selected beneficiaries. The interview guide was used to collect primary data from the beneficiaries of AC. A structured questionnaire with open ended and closed ended questions was used to collect data from the 10 key informants. Observation was also used only on the beneficiaries. It was done after the interviews. Secondary data from AC records was collected from Program operating manual/procedures and policies documents, Project selection criteria, grant approval procedures; Grant memorandum of agreements; KENSUP (2006-2009); and Projects documents (concept notes, project proposals and reports (progress, financial, and terminal). Validity was ensured by employing data triangulation technique to ensure that the strengths and weaknesses in each source were compensated when used together.

\section{THEORETICAL FRAMEWORK}

The study adopted the theoretical concept of sustainability within the context of the DFID's Sustainable Livelihood Approach. It was founded on the premise that development can refer either to deliberate attempts at progress through outside intervention, or to the people's own efforts to improve the quality of their lives (Carney, 2003). It consists of five major components that are related through sequential relationships and feedback which include:

\section{Vulnerability Context}

This describes the external uncontrollable factors that influence people's assets and livelihood opportunities. These factors are classified as: shocks (e.g environment and conflict-related); trends (e.g. resources, technology); and seasonality (e.g price fluctuations, employment opportunities). This study was able to examine the possible factors that affected strategies adopted by AC.

\section{Livelihood assets}

The assets are outlined in terms of five categories necessary for the pursuit of positive livelihood outcomes. These are human capital (amount and quality of knowledge and labor available in a household); natural capital (the quality and quantity of natural resources, ranging from fisheries to air quality); financial capital (savings and regular inflows of money); physical capital; i.e. the infrastructure, tools, and equipment used for increasing productivity); social capital (i.e. social resources, including networks for cooperation, mutual trust, and support).

\section{Transforming structures and processes}

Transforming structures and processes within the livelihoods framework are the institutions, organizations, policies and legislations that shape livelihoods. They operate at all levels, from household to the wider communities. Access, control and use of assets are influenced by the institutional structures and processes such as laws, policies and societal norms.

\section{Livelihood Strategies}

Livelihood strategies are the activities that generate the means for household survival (Ellis, 2000). Livelihood strategies change as the external environment over which people have little control changes. This study assessed the different livelihood strategies and discussed further how they enhanced beneficiaries' livelihood activities that culminated in ownership of different assets. 


\section{Livelihood Outcomes}

The word 'outcomes' is used rather than 'objective' in the DIFID framework because outcomes is considered a neutral term that reflects the aims of both DFID and its clients, whereas the term 'objectives' could imply top down objectives (Ellis, 2000). A focus on outcomes leads to a focus on achievements, indicators and progress.

\section{CONCLUSION}

The study established that the livelihood framework used should be based on the premise that the asset status of the poor is fundamental to understanding the options open to them. The five capitals i.e. human, social, natural physical must all be considered when establishing the right strategies for sustainability. The study also established that there are various events that can cause risk or vulnerability which should be anticipated and ways of mitigating or avoiding conflict planned in advance of implementation. That internal policies and legislations should be enabling to shape the choice of livelihoods strategies. The study also established that the beneficiaries should be involved in the planning of the strategies so that they own the activities and be willing to continue with them even after the support from the NGO is withdrawn or comes to an end. There should be focus on achievements, indicators and progress when implementing the strategies through a participatory enquiry involving all stakeholders Adventist Centre should develop standard guidelines and plan activities proportionally within the five categories or capitals.

\section{References}

ADAM, A.G. (2013). The influence of financial relations on sustaining rural livelihood in Sudan: Reflecting the significance of social capital in the village Al Dagag, North Kordofam State. Wien:LT.

Ahmed, I. A. (2012). Factors Influencing Sustainable Funding of Nongovernmental Organisations in Kenya: A Case Study of Sisters Maternity Home (SIMAHO) in Garissa. Unpublished Dissertation, Nairobi University.

Aipinge, H.N. (2015). An Analysis of the Sustainability of the United States Government (USG) Aid funded Nongovernmental Organisations (NGOs in the Namibian Health Sector). Unpublished Dissertation, Stellenbosch University.

Amagoh, A. \& Kabdiyeva, A. (2012). Management issues for improving NGO Sustainability in Kazakhstan. World Journal of Social Sciences, 2(3), 31-40.

Ameer, R., \& Othman, R. (2012). Sustainability practices and corporate financial performance: A study based on the top global corporations.

Bell, S. \& Morse, S. (2003) Measuring sustainability: learning by doing. London, Earthscan.

Claessens, S. (2011). Lessons from the Recent Financial Crisis for Reforming National and International Financial Systems: The Road Ahead to a Sustainable Global Economic System.

De Haan, L., Zoomers, A. 2005. Exploring the frontier of livelihoods research. Development and Change 36(1): 2747.

Ellis, F.(2000). Rural livelihoods and diversity in developing countries.. Oxford: Oxford University Press

Government of Kenya. (2011). Population and housing census: Analytical report on population projections, V11. Nairobi: CBS,MFP.

Journal of Business Ethics, 108(1), 61-79.

KENSUP (2009). Kenya National Slums Upgrading promotional leaflet. Kenya: Ministry of Housing

Lewis, D. (2006). The Management of Non-Governmental Development Organizations: An Introduction. Hoboken: Taylor \& Francis Ltd.

Matanga, F.K. (2010). NGOs and the politics of development in Africa Development 53(1): 114-119.

Miller, R.L. and J.D. Brewere, (2003) A-Z of social research. London: SAGE Publication

NGO Board. (2016). Notice to deregister NGOs. http://www.ngobureau.or.ke/

UN (2011) The millennium development goals report 2011. United Nations PUBLICATIONS 
USAID. (2009). NGO sustainability index for Sub-Saharan Africa (ist ed.). Pennsylvania Avenue, N.W: U.S. Agency for International Development 